Article

\title{
The Importance of Allelopathic Picocyanobacterium Synechococcus sp. on the Abundance, Biomass Formation, and Structure of Phytoplankton Assemblages in Three Freshwater Lakes
}

\author{
Iwona Bubak ${ }^{1, *}$, Sylwia Śliwińska-Wilczewska ${ }^{2}\left({ }^{\circ}\right.$, Paulina Głowacka $^{3}$, Agnieszka Szczerba $^{3}(1)$ \\ and Katarzyna Możdżeń ${ }^{4}$ \\ 1 Division of Hydrology, Institute of Geography, University of Gdansk, Bażyńskiego 4 St, P-80-309 Gdańsk, Poland \\ 2 Division of Marine Ecosystems Functioning, Institute of Oceanography, University of Gdansk, Avenue \\ Piłsudskiego 46, P-81-378 Gdynia, Poland; ocessl@ug.edu.pl \\ 3 Division of Geomorphology and Quaternary Geology, Institute of Geography, University of Gdansk, \\ Bażyńskiego 4 St, P-80-309 Gdańsk, Poland; paulina.glowacka@phdstud.ug.edu.pl (P.G.); \\ agnieszka.szczerba@phdstud.ug.edu.pl (A.S.) \\ 4 Institute of Biology, Pedagogical University of Krakow, Podchorążych 2 St., P-30-084 Kraków, Poland; \\ katarzyna.mozdzen@up.krakow.pl \\ * Correspondence: iwona.bubak@ug.edu.pl; Tel.: +48-58-523-65-31
}

Received: 29 February 2020; Accepted: 14 April 2020; Published: 16 April 2020

\begin{abstract}
The contribution of picocyanobacteria to summer phytoplankton blooms, accompanied by an ecological crisis, is a new phenomenon in Europe. This issue requires careful investigation. We studied allelopathic activity of freshwater picocyanobacterium Synechococcus sp. on phytoplankton assemblages from three freshwater lakes. In this study, the allelopathic activity of the Synechococcus sp. on the total abundance, biomass, as well as structure of the phytoplankton assemblages were investigated. Our results indicated that addition of exudates obtained from Synechococcus sp. affected the number of cells and biomass of the phytoplankton communities; the degree of inhibition or stimulation was different for each species, causing a change in the phytoplankton abundance and dominance during the experiment. We observed that some group of organisms (especially cyanobacteria from the genus Aphanothece, Limnothrix, Microcystis, and Synechococcus) showed tolerance for allelopathic compounds produced and released by Synechococcus sp. It is also worth noting that in some samples, Bacillariophyceae (e.g., Amphora pediculus, Navicula pygmaea, and Nitzschia paleacea) were completely eliminated in the experimental treatments, while present in the controls. This work demonstrated that the allelopathic activity exhibited by the Synechococcus sp. is probably one of the major competitive strategies affecting some of the coexisting phytoplankton species in freshwater ecosystems. To our best knowledge this is the first report of the allelopathic activity of Synechococcus sp. in the freshwater reservoirs, and one of the few published works showing allelopathic properties of freshwater picocyanobacteria on coexisting phytoplankton species.
\end{abstract}

Keywords: allelopathy; inland freshwater lakes; phytoplankton assemblages; picocyanobacteria blooms; Synechococcus sp.

Key Contribution: Our observations indicated that some phytoplankton species may show tolerance for allelopathic compounds produced and released by freshwater Synechococcus sp., which may be the result of coevolution during their coexistence in some freshwater ecosystem. Moreover, mutual stimulation of picocyanobacteria may explain their high abundances in the summer season in some freshwater reservoirs. This study suggests that the allelopathic effect may be dependent on the specificity of the target group and season. 


\section{Introduction}

Phytoplankton is the most numerous group of photosynthetic organisms [1], displaying a range of adaptational traits with regard to populating habitats and demonstrate a high resistance to adverse living habitats [2]. The structuring and dynamics of phytoplankton assemblages in freshwater ecosystems are driven by the relationships of phytoplankton with the chemical, physical, and biological parameters within the ecosystem [3-5]. Many planktonic algae, in particular blue-green algae (Cyanobacteria), are characterized by their considerable competitive potential that, in specific conditions, leads to the formation of blooms. The main reason for the forming of blooms in freshwater reservoirs is eutrophication, described as the enrichment of water bodies with nutrients [6-8]. Furthermore, chemically mediated interactions, so-called allelopathy, between the algal components of the aquatic ecosystem could also significantly influence phytoplankton succession $[9,10]$.

In general, most studies of cyanobacterial and microalgal allelopathy have been performed in marine environments (e.g., [11-16]); however, little is known about this phenomenon among freshwater picocyanobacteria. In fact, only one related article on allelopathic activity in freshwater picocyanobacteria on coexisting microalgae was found. In this paper, Kovacs et al. [17] for the first time described that the freshwater picocyanobacterium Cyanobium gracile Rippka and Cohen-Bazire has a strong negative effect on green alga Scenedesmus quadricauda (Turpin) Brébisson. Most of the work on the allelopathic activity of picoplanktonic cyanobacteria of the genus Synechococcus has been described for the strain CCBA BA-124, originating from the Baltic Sea [18-25]. Additionally, Konarzewska et al. [26] showed allelopathic properties of Baltic Synechococcus sp. CCBA BA-120 and CCBA BA-132. The allelopathic activity between marine Synechococcus strains CC9605, CC9311, and WH8102 has also been showed by Paz-Yepes et al. [27]. There are also reports of allelopathic activity of marine picocyanobacteria of the genus Synechocystis CCBA MA-01 [28]. In these studies, it was shown that picocyanobacteria of the genus Synechococcus and Synechocystis can produce and release unidentified allelopathic compounds that have both a negative and positive effect on selected cyanobacteria and microalgae. The picocyanobacteria Synechococcus sp., Synechocystis sp., and Cyanobium sp. displayed a negative effect on the survival of selected animals [29-32]. These results obtained indicated that freshwater picocyanobacteria may serve as a potential source of interesting bioactive compounds, whose mode of action on target organisms requires detailed investigation.

Picocyanobacteria are important components and primary producers in aquatic ecosystems [33-35]. In the past, picocyanobacteria were described as a non-blooming group [36]; however, some studies demonstrated the potentially dangerous character of picocyanobacterial blooms [37-40]. Those bloom have caused profound transformations in the aquatic ecosystem and resulted in the loss of fish and clam resources. Furthermore, the authors examined that the picocyanobacterial bloom was accompanied by great changes in the benthic habitats. What is more, future climate change scenarios predict rising temperatures [41], which can act as a catalyst for the global expansion of harmful picocyanobacterial blooms [42,43].

As mentioned above, picoplanktonic cyanobacteria are known to produce and release a wide spectrum of biologically active compounds, whose harmfulness to other organisms has been demonstrated [44]. At the same time, the functional role of these compounds, particularly in terms of the ecology of the picocyanobacteria that produce them, remains largely unknown. Therefore, in this study, we attempted to determine the allelopathic effect of the freshwater picocyanobacterium Synechococcus sp. on plankton assemblages. This work emphasizes the importance of studying the allelopathic activity of picocyanobacteria in freshwater reservoirs.

\section{Results}

\subsection{Abundance, Biomass, and Structure of the Phytoplankton Community}

Altogether, 116 taxa of phytoplankton were revealed in the studied lakes: Łazduny (ŁL), Rzéśniki (RL), and Żabińskie (ŻL). A list of species detected in $€ L, R L$, and $\dot{Z} L$ in the study period is shown in Table S1 (in Supplementary Material). Analyzing the number of cells, it was shown that cyanobacteria dominated in all lakes throughout most of the studied depths. The highest number of cyanobacteria 
cells were recorded in ŻL in July $\left(117.8 \cdot 10^{6}\right.$ cell $\left.\mathrm{mL}^{-1}\right)$ and in RL in July and August $\left(52.5 \cdot 10^{6} \mathrm{cell} \mathrm{mL}^{-1}\right.$ and $46.4 \cdot 10^{6}$ cell $\mathrm{mL}^{-1}$, respectively).

In $€ \mathrm{~L}$, Bacillariophyceae dominated in biomass in each month as well as depth, constituting about $60 \%$ of the total biomass. Biomass of the other groups was clearly lower (Figure 1A). In RL, Bacillariophyceae also dominated in biomass, constituting $42 \%$ of the total biomass of the phytoplankton assemblage and the largest share of this class was recorded from May to July at a depth of $1 \mathrm{~m}$. It was also found that Chlorophyceae, Dinophyceae, and Cyanophyceae amounted to $20 \%, 13 \%$, and $13 \%$ of the total biomass, respectively (Figure 1B). Bacillariophyceae also dominated in ŻL (38\% of the total biomass). Furthermore, ŻL had a significant share of the Chlorophyceae (12\%) and Charophyceae $(21 \%)$ at a depth of $1 \mathrm{~m}$ (Figure 1CSurprisingly, Dinophyceae dominated in biomass in June at a depth of $1 \mathrm{~m}(56 \%)$, and of Cyanophyceae in July at a depth of $10 \mathrm{~m}$ ( $87 \%$ of biomass).
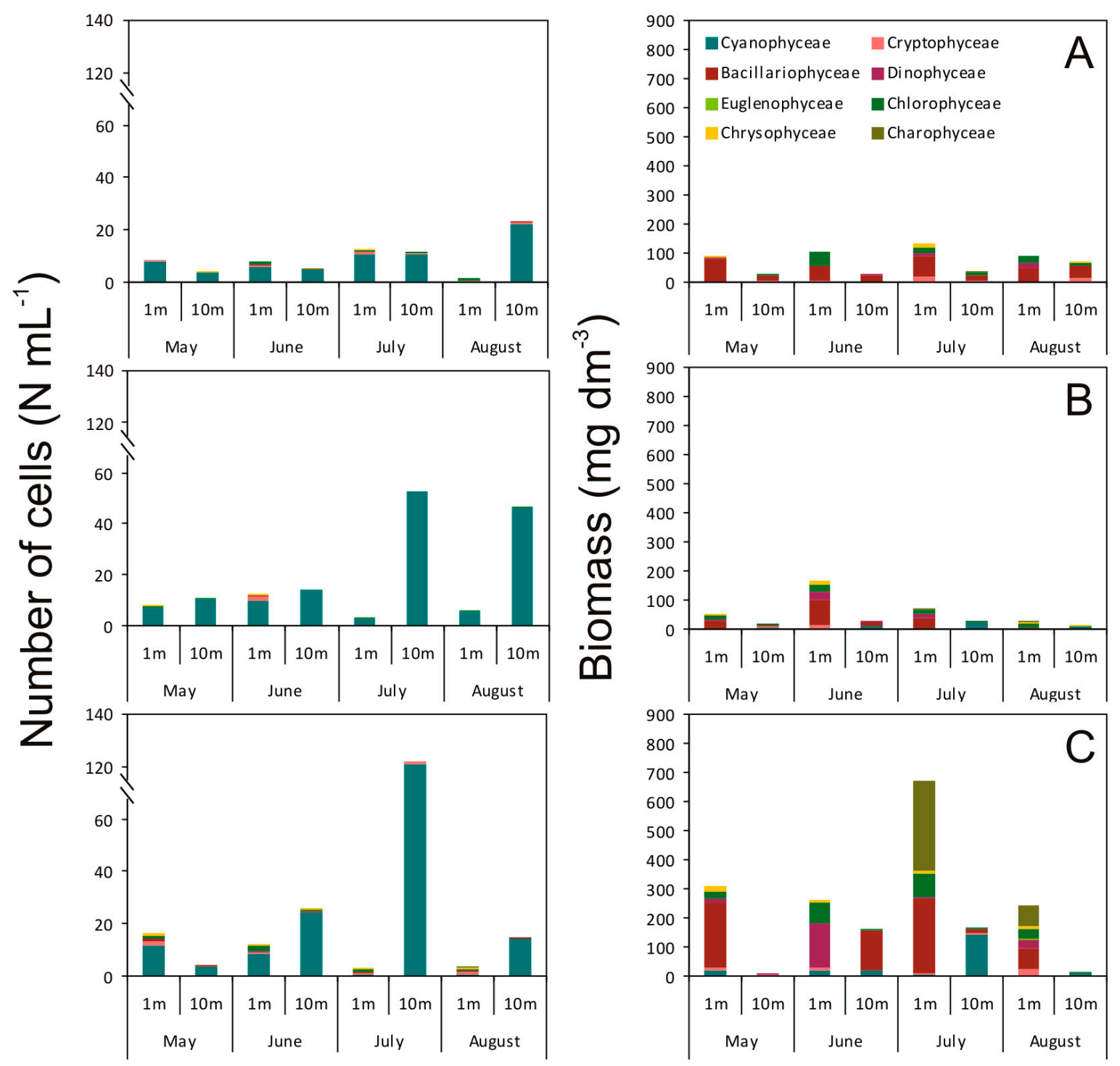

Figure 1. The number of cells $\left(10^{6}\right.$ cell $\left.\mathrm{mL}^{-1}\right)$ and biomass of each phytoplankton class in the Łazduny (ŁL) (A), Rzęśniki (RL) (B), and Żabińskie (ŻL) (C) lakes at a depth of $1 \mathrm{~m}$ and $10 \mathrm{~m}$ during the study period.

\subsection{Effect of Picocyanobacterial Exudates on the Abundance, Biomass, and Structure of Phytoplankton Assemblages}

The addition of exudates obtained from Synechococcus sp. affected the number of cells, biomass, as well as the structure of the phytoplankton communities (Figures 2-4). It was observed that 
Cyanophyceae dominated in abundance in all tested samples. The only exception was the ŻL, where Chlorophyceae, Charophyceae, and Bacillariophyceae dominated in June. On the other hand, Bacillariophyceae generally dominated in biomass of the phytoplankton assemblages (Figures 2 and 3).

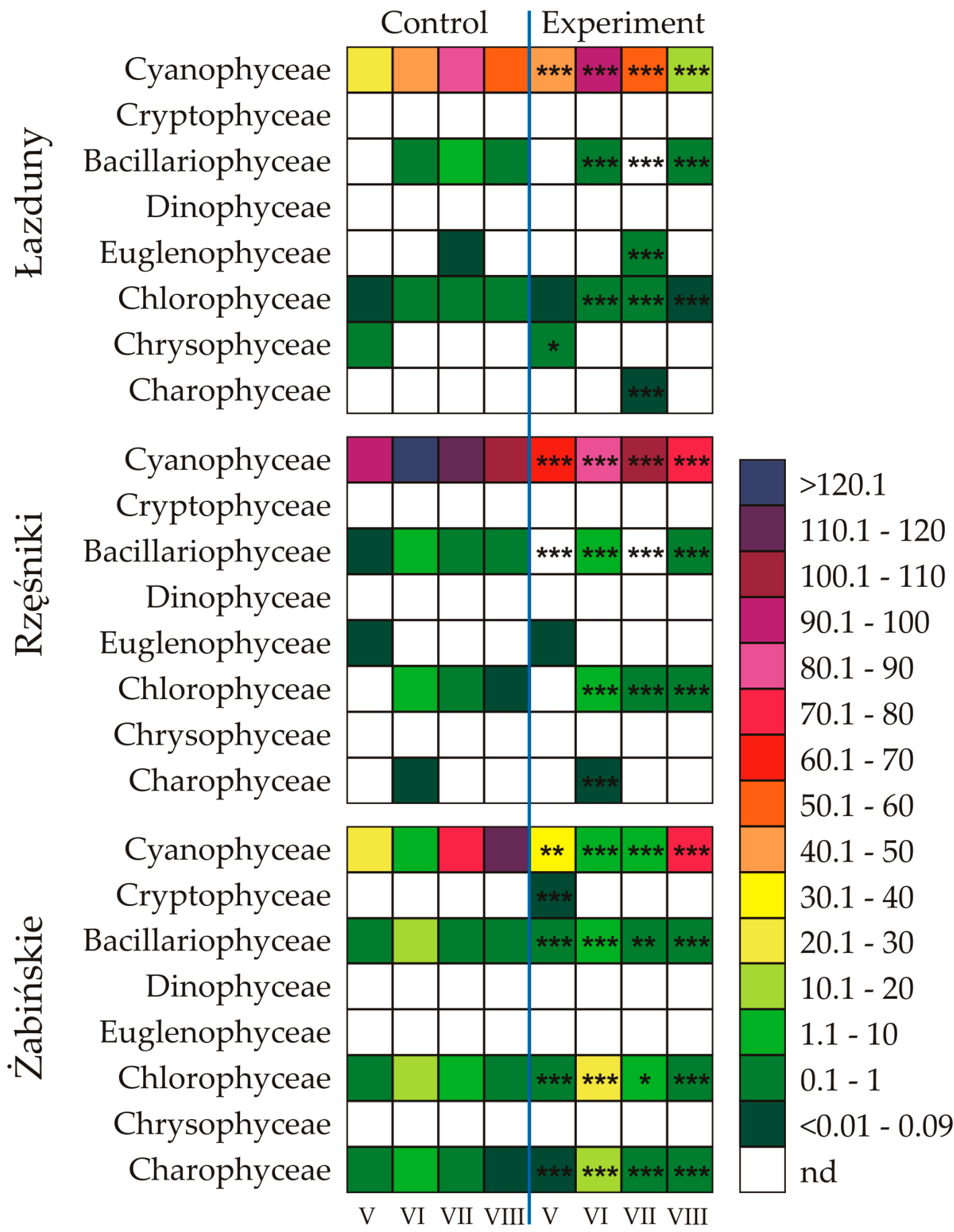

Figure 2. List of class of phytoplankton in the studied lakes, the number of cells $\left(10^{6}\right.$ cell $\left.\mathrm{mL}^{-1}\right)$ of species in the controls, and the experiments after 7 days of exposition to the exudates from Synechococcus sp. measured for each month $(n=3$, mean $\pm \mathrm{SD})$. Asterisks indicate statistically significant difference compared with the control (ANOVA test, ${ }^{*} p<0.05 ;{ }^{* *} p<0.01$; ${ }^{* * *} p<0.001$; nd-not detected).

Our study showed that the Synechococcus sp. exudates had a statistically significant effect on the number of Cyanophyceae cells in ŁL (Figure 2). It was shown that in May and June the Cyanophyceae cell number increased by $200 \%$ (ANOVA, $p<0.001)$ and $240 \%(p<0.001)$, respectively, in relation to 
the control treatment. In the following months, the number of Cyanophyceae cells was significantly inhibited and amounted to $60 \%$ in July $(p<0.001)$ and $30 \%$ in August $(p<0.001)$, compared to the control samples. Similarly, the number of Bacillariophyceae cells was inhibited in June and July and stimulated in the last studied month, i.e., in August. The cell number of Bacillariophyceae in June was $55 \%(p<0.001)$ relative to the control. It is worth noting that in July, Bacillariophyceae were completely eliminated in the experimental sample, while present in the control sample. In August, however, 150\% $(p<0.001)$ stimulation of Bacillariophyceae growth relative to the control conditions was noted. It was shown that the exudates obtained from the Synechococcus sp. significantly stimulated the abundance of Euglenophyceae in July in $Ł L$, which was $230 \%(p<0.001)$ compared to the control. In the same month, a small amount of Charophyceae was also noted in the experimental sample, which were not recorded in the control sample. In turn, the exudates from picocyanobacterium negatively affected organisms belonging to the Chrysophyceae, whose number in May was $70 \%(p<0.05)$ compared to the control, and the number of Chlorophyceae, whose number was 75\% in June $(p<0.001), 60 \%(p<$ 0.001) in July, and only 5\% $(p<0.001)$ in August.

It was noted that Synechococcus sp. exudates significantly inhibited the cell numbers of Cyanophyceae in RL in all the studied months (Figure 2). The numbers of Cyanophyceae cells in May, June, July, and August were 70\% $(p<0.001), 70 \%(p<0.001), 90 \%(p<0.001)$, and 70\% $(p<$ $0.001)$, respectively, compared to the control samples. It was also shown that the exudates obtained from Synechococcus sp. had a negative effect on the number of cells of Bacillariophyceae and Charophyceae in June. Their overall number of cells in the experimental sample was $80 \%(p<0.001)$ and only $5 \%(p<0.001)$, respectively, compared to the control treatment. It is worth noting that in May and July, Bacillariophyceae were completely eliminated in the experimental sample, while present in the controls. In addition, it was found that the population of Bacillariophyceae was, similarly to that recorded in $€ \mathrm{~L}$, stimulated by $270 \%$ in August $(p<0.001)$. It was also shown that the exudates from picocyanobacterium stimulated the abundance of Chlorophyceae in RL. In June, July, and August, the number of Chlorophyceae cells increased by 130\% $(p<0.001), 150 \%(p<0.001)$, and about $480 \%(p<$ $0.001)$, respectively, compared to the control treatment.

The picocyanobacterium Synechococcus sp. exudates had a statistically significant effect on the cell number of Cyanophyceae in ŻL (Figure 2). In May and June, as in the case of ŁL, the number of Cyanophyceae increased statistically and amounted to $115 \%(p<0.01)$ and $200 \%(p<0.001)$, respectively, in relation to the control. In turn, in the following months, the number of Cyanophyceae cells was significantly inhibited and amounted to only $10 \%(p<0.001)$ in July and $60 \%(p<0.001)$ in August, compared to the control samples. Synechococcus sp. exudates significantly inhibited the number of Bacillariophyceae cells in ŻL in all the studied months. The cells numbers of Bacillariophyceae in May, June, July, and August were as follow: 80\% ( $p<0.001), 10 \%(p<0.001), 85 \%(p<0.01)$, and 50\% $(p<$ $0.001)$, respectively, compared to the control sample. It was also shown that the exudates from the picocyanobacterium generally stimulated the number of Chlorophyceae and Charophyceae cells in ŻL. In June, July, and August, the number of Charophyceae cells increased by $160 \%(p<0.001), 210 \%(p<$ $0.001)$, and about $600 \%(p<0.001)$, respectively, compared to the control. In contrast, stimulation of Chlorophyceae was 210\% in May ( $p<0.001), 140 \%$ in June $(p<0.001)$, and 200\% in August $(p<0.001)$. Furthermore, in May, a small amount of Cryptophyceae was noted in the experimental sample while in the control sample they were not recorded. 

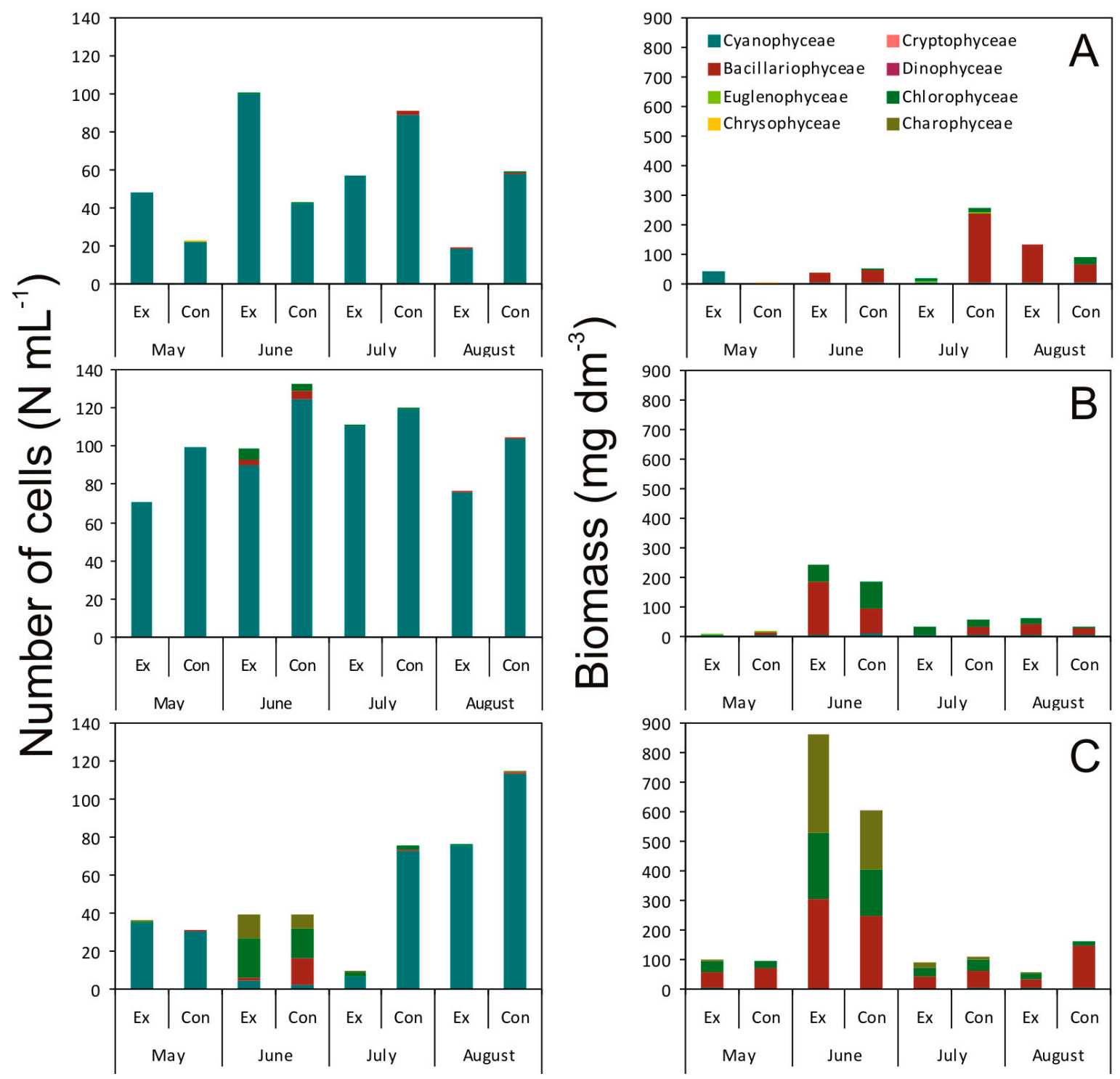

Figure 3. The number of cells $\left(10^{6}\right.$ cell $\left.\mathrm{mL}^{-1}\right)$ and biomass of taxa present in the $€ L$ (A), RL (B), and ŻL (C) lakes in the control (Con) and the experimental samples (Ex) measured during the study period $(n$ $=3$ ).

It was shown that the exudates from Synechococcus sp. significantly reduced the biomass of Bacillariophyceae in May, June, and July in ŁL (Figure 3A). Moreover, it is worth noting that in May and July, Bacillariophyceae were completely eliminated in the experimental samples, while present in the controls. In May, it was found that the Synechococcus sp. exudates caused stimulation of Cyanophyceae biomass. Their biomass was about 3550\% compared to the control sample. Furthermore, it was found that Cyanophyceae: Aphanocapsa holsatica (Lemmermann) G.Cronberg and Komárek, Aphanocapsa incerta (Lemmermann) G.Cronberg and Komárek, and Snowella atomus Komárek and Hindák were recorded in both the control and experimental samples. However, the species that were present only in the experimental sample were Aphanothece sp. and Woronichinia naegeliana (Unger) Elenkin (Table S2 in Supplemental Material). In August, in turn, it was shown that the picocyanobacterial exudates caused stimulations of Bacillariophyceae, whose biomass was $210 \%$ compared to the control. In the same month, there was a decrease in biomass of Chlorophyceae in the experimental sample. Species that dominated in the control were Coelastrum microporum Nägeli, Monoraphidium contortum (Thuret) Komárková-Legnerová, Monoraphidium minimum (Nägeli) 
Komárková-Legnerová, and Tetrastrum staurogeniaeforme (Schröder) Lemmermann, while only $M$. minutum was recorded in the experimental sample.

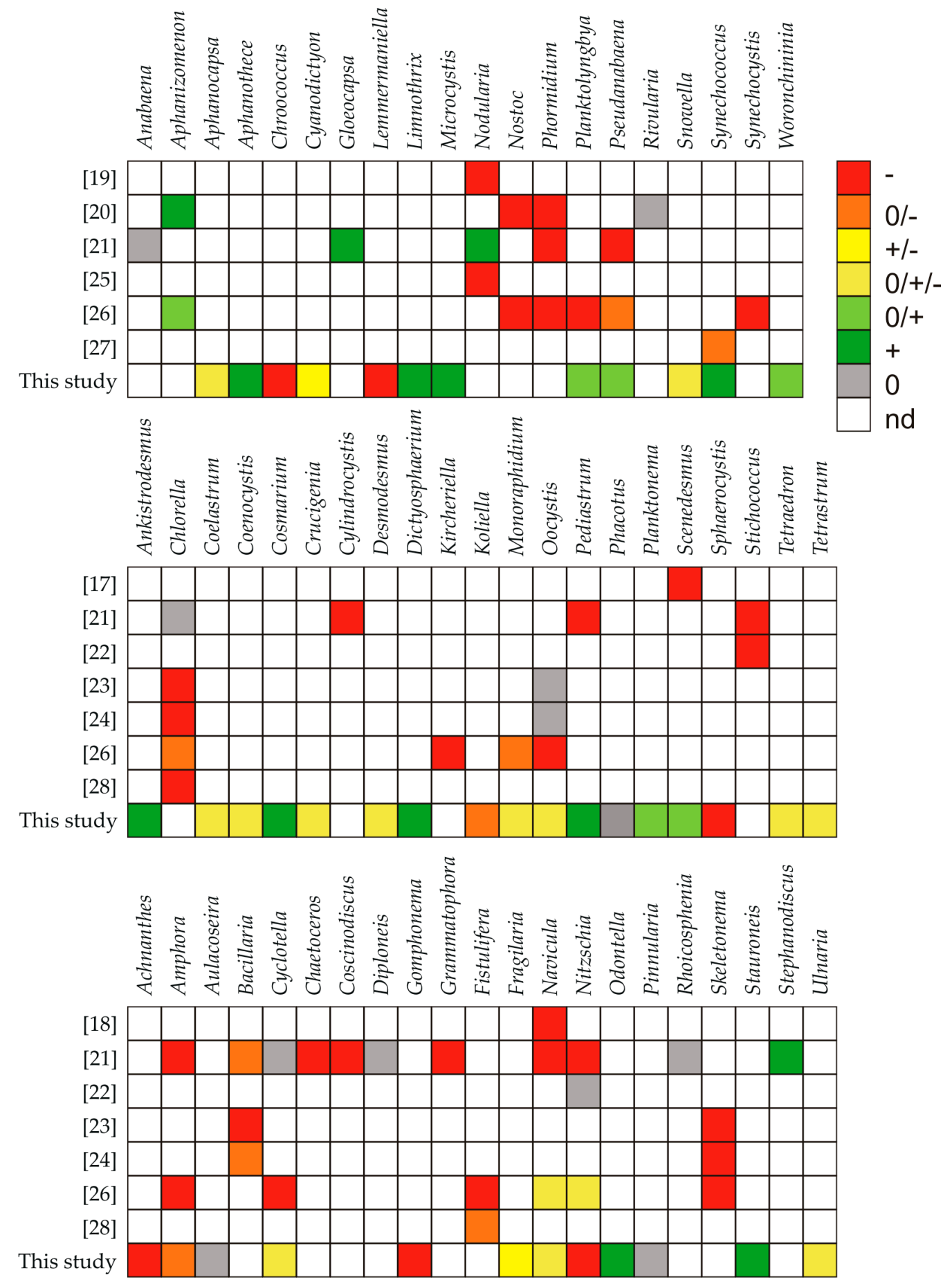

Figure 4. List indicating the allelopathic activity of picocyanobacteria against other genera of cyanobacteria and microalgae with the references (- means inhibiting effects, + means stimulating effects, and 0 means a lack of an effect; nd-not detected).

It was found that higher overall phytoplankton biomass was observed in the RL in the control in May and July. In these months, as was the case in $€ L$, it was noted that Bacillariophyceae were completely eliminated in the experimental samples, compare to the control samples. Surprisingly, in 
June an increase in the overall biomass of Bacillariophyceae was noted in the experimental treatment, namely Amphora pediculus (Kützing) Grunow, Navicula sp., and Pinnularia sp. (Table S3). Their biomass was almost $200 \%$ compared to the control sample. In August, it was shown that the picocyanobacterial exudates caused stimulations of Bacillariophyceae and Chlorophyceae, whose biomass was $170 \%$ and $520 \%$, respectively, compared to the control treatment (Figure 3B).

Generally, in ŻL, the exudates from Synechococcus sp. had a negative effect on the biomass of phytoplankton assemblages throughout the entire studied period (Figure 3C80\% $(p<0.01), 10 \%(p<$ $0.001), 80 \%(p<0.01)$, and $20 \%(p<0.001)$, respectively, relative to the control treatments. Species that were present in the control but were eliminated in the experimental sample were Achnanthes sp., A. pediculus, Navicula pygmaea Kützing, and Nitzschia paleacea (Grunow) Grunow (Table S4). In May, June, and August it was noted that the picocyanobacterial exudates caused stimulations of Chlorophyceae, whose biomass was $180 \%, 160 \%$, and $160 \%$, respectively, compared to the controls. The species that dominated in both the control and experimental samples were Desmodesmus communis (E.Hegewald) E.Hegewald, M. contortum, M. minutum, and Tetraëdron minimum (A.Braun) Hansgirg (Table S4). It was also shown that the exudates from Synechococcus sp. in June, July, and August caused stimulations of Charophyceae, whose biomass was $160 \%, 200 \%$, and $610 \%$, respectively, compared to the control treatments. It is worth mentioning that the only species recorded in the samples was Koliella longiseta (Vischer) Hindák (Table S4).

We also showed that different phytoplankton species responded differently to Synechococcus sp. exudates (Figure 4). It was found that Cyanophyceae from the genus Aphanothece, Limnothrix, Microcystis, Planktolyngbya, Pseudanabaena, Synechococcus, and Woronchininia, as well as Chlorophyceae and Charophyceae (Ankistrodesmus, Cosmarium, Dictyosphaerium, Pediastrum, Planktonema, and Scenedesmus) showed tolerance for allelopathic compounds produced and released by freshwater Synechococcus sp. in each lake. In our work we have shown that Synechococcus sp. also stimulated the growth of some species of Bacillariophyceae, especially from the genus Odontella and Stauroneis. On the other hand, Chroococcus and Lemmermaniella (Cyanophyceae), Sphaerocystis and Koliella (Chlorophyceae), as well as Achnanthes, Amphora, Gomphonema, and Nitzschia (Bacillariophyceae) were strongly inhibited by this picocyanobacterium.

\section{Discussion}

We showed that phytoplankton assemblages responded differently to Synechococcus sp. allelopathy. In this work we demonstrated that these differences in susceptibility are found between major taxonomic groups and even between individual species. This differential effect on microalgae species suggests that picocyanobacterial exudates have an important role in structuring phytoplankton assemblages.

The allelopathic activity between cyanobacteria that occur in the same ecosystem is an interesting concept in terms of evolution. The literature data indicated that some Cyanophyceae could produce the allelopathic compounds that affect the growth of other cyanobacterial species (e.g., [45-53]). What is more, recent research showed that picoplanktonic cyanobacteria are also capable of allelopathic effects on other cyanobacteria. Paz-Yepes et al. [27] used liquid and plate assays to demonstrate Synechococcus sp. inhibited growth of other Synechococcus sp. strains. Barreiro Felpeto et al. [25] demonstrated that Synechococcus sp. also had a strong inhibitory effect on Nodularia spumigena Mertens ex Bornet and Flahault and, surprisingly, there was no target organism reciprocal effect. Śliwińska-Wilczewska et al. [20] described the adverse impact of Synechococcus sp. filtrate against Nostoc sp. and Phormidium sp. Moreover, the authors showed that the addition of picocyanobacterial filtrate stimulated the growth of Aphanizomenon flos-aquae Ralfs ex Bornet and Flahault and had no allelopathic effects on Rivularia sp. Śliwińska-Wilczewska et al. [21] also indicated that the degree of inhibition was different for each species, causing a change in the phytoplankton abundance and dominance during the experiment. The authors demonstrated that the picocyanobacterium Synechococcus sp. filtrate generally had an inhibitory effect on the phytoplankton community, except for the cyanobacteria N. spumigena and Gloeocapsa sp., which increased in the filtrate treatment. Recent studies have also shown that Synechococcus 
sp. had a strong inhibitory effect on other cyanobacteria from the genus Phormidium, Planktolyngbya, Pseudanabaena, Nostoc, and Synechocystis sp. while stimulating Aphanizomenon sp. [26]. It is still not understood precisely why cyanobacteria produce compounds that perform stimulatory activity. Some researchers believe that cyanobacteria are capable of secreting some autostimulators that accelerate the development of the same species in the environment [54]. Moreover, it is commonly known that in laboratory experiments using monocultures, generally, cyanobacteria inhibit the growth of other cyanobacteria [55,56]; however, in natural assemblies, many co-occurring species could have developed some protective mechanisms against cyanobacterial metabolites and even benefit from them [57]. Our observations indicated that some Cyanophyceae (especially cyanobacteria from the genus Aphanothece, Limnothrix, Microcystis, and Synechococcus) may show tolerance for allelopathic compounds produced and released by freshwater Synechococcus sp., which may be the result of coevolution during their coexistence in some freshwater ecosystem. It is worth noting here that mutual stimulation of picoplanktonic cyanobacteria may indicate their competitive advantage and explain their high abundances in the summer season in some freshwater reservoirs.

Studies have shown that cyanobacteria can also affect the growth of some Chlorophyceae and Charophyceae species [13,50-52,58-63] and picoplanktonic cyanobacteria deserved special attention here. Śliwińska-Wilczewska et al. [22] demonstrated that both the addition of Synechococcus sp. cell-free filtrate and co-culture inhibited the growth of Stichococcus bacillaris Nägeli. Moreover, Śliwińska-Wilczewska and Latała [23] and Śliwińska-Wilczewska et al. [24] noted that Synechococcus sp. also inhibited the growth of Chlorella vulgaris Beyerinck [Beijerinck]. Recently, Kovács et al. [17] demonstrated that the freshwater picocyanobacterium C. gracile had a substantial negative impact on the coexisting S. quadricauda. Konarzewka et al. [26] also showed strong inhibition of Chlorophyceae growth due to exudates from three different Synechococcus phenotypes. Similar observations have been also made for other picocyanobacterium Synechocystis sp. [28]. Contrary to that, Synechococcus sp. filtrate had no allelopathic effects on Oocystis submarina Lagerheim $[23,24]$. In our work we have shown that Synechococcus sp. also stimulated the growth of some Chlorophyceae and Charophyceae (e.g., Ankistrodesmus, Cosmarium, Dictyosphaerium, and Pediastrum). Those results may indicate that cyanobacteria are capable of producing more than one bioactive compound that affect different target organisms. Allelopathic effects recognized in cyanobacteria may play an important role in the deterrence of target organisms from colonization of cyanobacteria cells [64]. Our findings suggest that allelopathic compounds secreted by the picocyanobacterium Synechococcus sp. may be responsible for their natural selection and ecological succession by inhibiting co-occurring competitive Chlorophyceae and Charophyceae species, especially from the genus Sphaerocystis and Koliella. This work also demonstrated that freshwater picocyanobacterium can affect the phytoplankton community differently, depending on the coexisting species.

Bacillariophyceae seem to be very sensitive to allelopathic compounds; some studies documented the allelopathic effect of cyanobacteria on selected diatoms species [45,59,65-67]. Picoplanktonic cyanobacteria may also affect the occurrence of Bacillariophyceae (Figure 4). Śliwińska-Wilczewska et al. [18] described that the picocyanobacterium Synechococcus sp. affected coexisting diatom Navicula perminuta Grunow negatively; it was the first of such a report in the literature. One year later, Śliwińska-Wilczewska et al. [21] examined the influence of allelopathic compounds on the growth, total abundance, and composition of a phytoplankton community by adding the cell-free filtrate of Synechococcus sp. into the medium. That study pointed to the diatoms of the genera Navicula, Chaetoceros, Amphora, Coscinodiscus, Grammatophora, and Nitzschia as the most allelochemical-sensitive organisms. Moreover, Śliwińska-Wilczewska and Latała [23], Śliwińska-Wilczewska et al. [24], and Konarzewska et al. [26] demonstrated that the addition of Synechococcus sp. filtrate strongly inhibited the growth of Skeletonema marinoi Sarno and Zingone. In contrast, Śliwińska-Wilczewska et al. [22] showed that Nitzschia dissipata (Kützing) Rabenhorst was not affected by the picocyanobacterial filtrate or co-culture. It was also found that marine Synechocystis sp. was able to inhibit Fistulifera sp. growth [28]. The susceptibility of target Bacillariophyceae to allelochemicals may depend on the nature of allelopathic 
compounds to which they are exposed, because the same target organisms may responsd differently to the exudates obtained from different donor organisms. Additionally, some co-evolutionary aspects may contribute to the observed results [45]. Diatom blooms usually do not co-exist with the massive cyanobacterial blooms. Therefore, in a natural environment, Bacillariophyceae generally do not have the opportunity to develop any defense mechanism for the allelopathic compounds secreted by cyanobacteria; it is likely a reason of the picocyanobacterial, allelopathic, effect-driven significant inhibition of diatom growth (especially from the genus Achnanthes, Gomphonema, and Nitzschia) in the studied freshwater reservoirs. It is worth mentioning here that most of the cyanobacterial allelochemicals are still unknown. Therefore, demonstrating which of the allelopathic compounds of Synechococcus sp. are responsible for the observed effects requires further, detailed research.

This work clearly demonstrates that the allelopathic activity exhibited by the Synechococcus sp. is probably one of the major competitive strategies affecting some of the coexisting phytoplankton species in freshwater ecosystems. Coevolution is hypothesized to be the main reason explaining the differences in phytoplankton susceptibility to picocyanobacterial exudates. Our observations indicated that (i) some phytoplankton species may show tolerance for allelopathic compounds produced and released by freshwater Synechococcus sp., which may be the result of coevolution during their coexistence in some freshwater ecosystem; (ii) mutual stimulation of picocyanobacteria may explain their high abundances in the summer season in some freshwater reservoirs; and (iii) the allelopathic effect may be dependent on the specificity of the target group and season. To our best knowledge this is the first report of the allelopathic activity of Synechococcus sp. in freshwater reservoirs, and one of the few published works showing allelopathic properties of freshwater picocyanobacteria on coexisting phytoplankton species. Therefore, to fully understand the allelopathic effects in aquatic environments, studies on different phytoplankton assemblages in many freshwater ecosystems are still needed to be performed.

\section{Materials and Methods}

\subsection{Study Sites}

The studied lakes are located in northeastern Poland in the Masurian Lakeland (Figure 5). This region is characterized by well-preserved postglacial landforms with the highest areal density of lakes in Poland [68]. The investigated lakes are small and relatively deep, but they are different in terms of morphometry, trophic status, hydrological regime, and catchment size (Table 1).

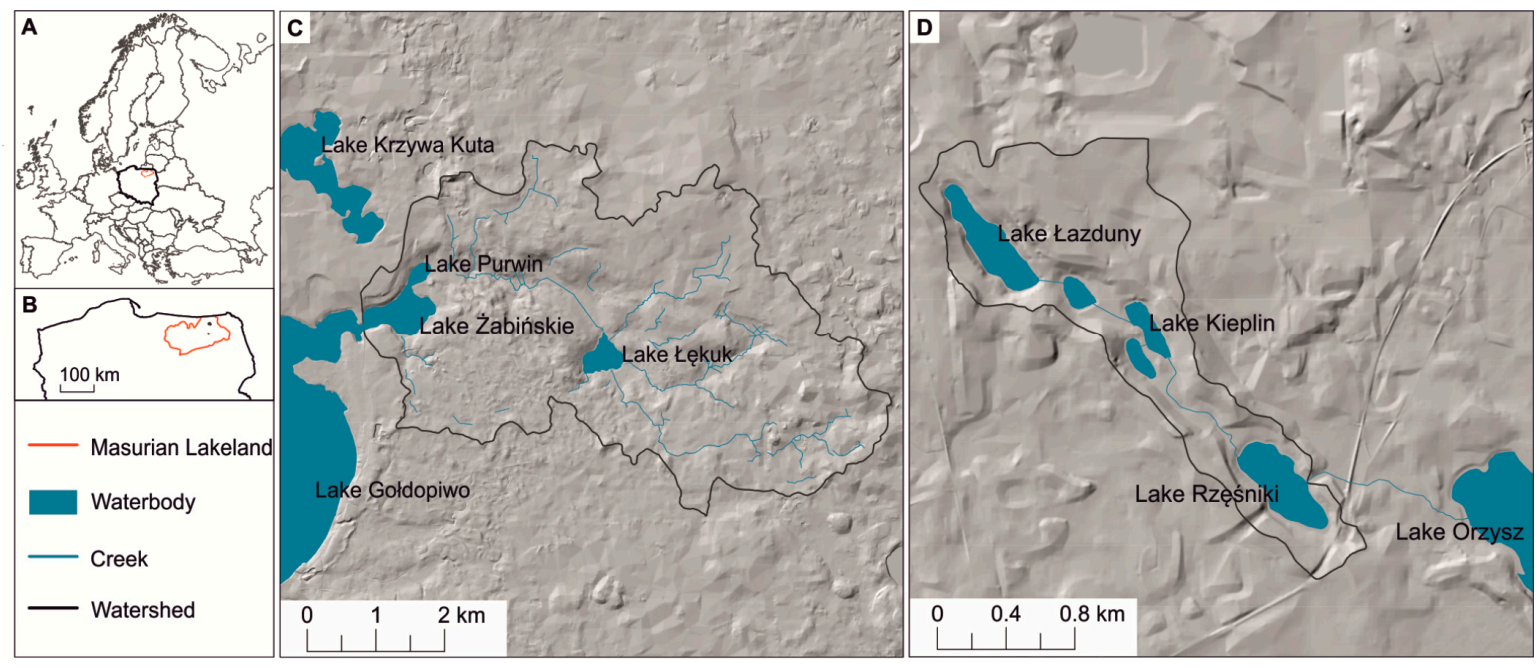

Figure 5. Localization of the studied lakes in Masurian Lakeland, north-eastern Poland. (A) Poland in Europe; (B) the Masurian Lakeland in Poland; (C) the watershed of LZ; and (D) the watersheds of LE and LR. 


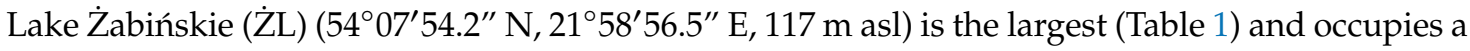
glacially eroded depression formed during Vistulian glaciation (ca. $15.2 \mathrm{kaBP}$ ) [69]. The total catchment has a surface of $24.6 \mathrm{~km}^{2}$ and it is mostly covered by forests (65\%). ŻL has three inflows, a major one from the northeastern side (from Lake Purwin) and two smaller creeks flowing from the south and southeastern side. The outflow drains water to the larger lake Gołdopiwo located in the west (Figure 5). Carlson's [70] Trophic State Index (TSI) (determined on the base of chlorophyll- $a$ concentration, total phosphorus concentration and Secchi disc transparency) indicate the eutrophic status of ŻL.

Table 1. Characteristic features of the studied lakes and their catchments [71].

\begin{tabular}{lccc}
\hline \multirow{2}{*}{ Parameter } & \multicolumn{3}{c}{ Lake } \\
\cline { 2 - 4 } & Lazduny & Rzęśniki & Żabińskie \\
\hline Surface (ha) & 10.6 & 12.0 & 41.6 \\
Volume (tys $\left.\mathrm{m}^{2}\right)$ & 964.6 & 1111.8 & 5072.8 \\
Maximum depth (m) & 22.4 & 26.0 & 44.4 \\
Average depth (m) & 9.1 & 7.8 & 12.2 \\
Maximum length (m) & 790 & 700 & 1073 \\
Maximum width (m) & 210 & 280 & 635 \\
Length of shoreline (m) & 1880 & 1700 & 2846 \\
Shoreline development index & 1.6 & 1.3 & 1.2 \\
Exposure index & 3.4 & 1.8 & 3.4 \\
Hydrological type & outflow lake & flow lake & flow lake \\
Total surface of catchment $\left(\mathrm{km}^{2}\right)$ & 1.94 & 1.94 & 24.6 \\
\hline
\end{tabular}

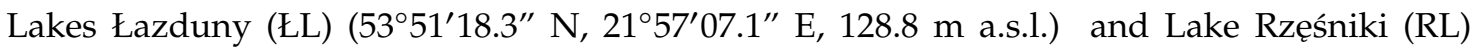
$\left(53^{\circ} 50^{\prime} 30.0^{\prime \prime} \mathrm{N}, 21^{\circ} 58^{\prime} 35.9^{\prime \prime} \mathrm{E}, 125.3 \mathrm{~m}\right.$ a.s.1.) were formed probably by the melting of dead ice in a deep channel of a glacial outwash plain. The lakes have a common catchment (total surface area of $\left.1.94 \mathrm{~km}^{2}\right)$ covered by coniferous forests $(85 \%)$ and also have similar basic morphometric parameters (Table 1). ŁL is an outflow lake, from which waters flows through two small and shallow water bodies and enters RL in its northwestern part. Outflow from RL supplies water to the Lake Orzysz located in the south-east (Figure 5). The TSI of ŁL and RL indicate the mezotrophic lake state of both.

\subsection{Determination of Abundance, Biomass, and Structure of the Phytoplankton Community}

Samples of phytoplankton were collected from $€ L$, RL, and ŻL with 1-month intervals from May to August 2019 (Table 2). Samples were taken from the $1 \mathrm{~m}$ and $10 \mathrm{~m}$ depth. During field tests, the physical and chemical parameters (temperature, conductivity, $\mathrm{pH}$, oxygen saturation and concentration, turbidity) of the water column were measured using a multiparameter sonde YSI 6820 meter (YSI, Yellow Spring, USA). The concentrations of nutrients (TN and TP) were measured using colorimetric methods and a Spectroquant NOVA 400 spectrophotometer (Merck, Darmstadt, Germany).

Plastic bottles were used to collect phytoplankton. The collection and processing of materials was carried out according to generally accepted methods in algology—water in each carboy was mixed, then a $500 \mathrm{~mL}$ sample was taken from each carboy and fixed with $5 \mathrm{~mL}$ of Lugol's solution. The pre-labeled sample bottles were transported to the laboratory for analysis [72]. International handbooks were used to identify algae [2,73], and the taxa names were adopted to the international system in Algaebase [74].

For quantitative analysis, including the identification, enumeration, and calculation of biovolumes of Lugol's iodine preserved water samples, Utermöhl's inverted-microscope method was applied. The preserved samples were thoroughly mixed, and a sub-sample of known volume was placed in a sedimentation chamber of 5 to $100 \mathrm{~mL}$ capacity (Utermöhl's plankton chambers or similar are recommended). Cyanobacteria and algae belonging to the phytoplankton community were counted and identified using an inverted microscope (Nikon, Japan). The average number of individuals/transect was converted into a population density unit (ind. $\mathrm{mL}^{-1}$ ). Population density data were translated into 
phytoplankton biomass by taking into account differences in the cell size of a particular taxa. For the calculation of the specific cell volumes, simple geometric models (e.g., sphere, ellipsoid, cylinder) were used [75].

Table 2. Physicochemical parameters of the water of the studies lakes during the study period.

\begin{tabular}{|c|c|c|c|c|c|c|c|}
\hline Lake & Month & $\begin{array}{l}\text { Depth } \\
\text { [m] }\end{array}$ & $\mathrm{T}\left({ }^{\circ} \mathrm{C}\right)$ & $\mathrm{pH}$ & $\begin{array}{c}\text { EC } \\
\left(\mu S \cdot \mathrm{cm}^{-1}\right)\end{array}$ & $\begin{array}{c}\text { TP } \\
\left(\mathrm{mg} \mathrm{P} \cdot \mathrm{dm}^{-3}\right)\end{array}$ & $\begin{array}{c}\mathrm{TN} \\
\left(\mathrm{mg} \mathrm{N} \cdot \mathrm{dm}^{-3}\right)\end{array}$ \\
\hline \multirow[t]{8}{*}{ Łazduny } & \multirow[t]{2}{*}{ May } & 1 & 12.9 & 8.5 & 383 & 0.08 & 0.04 \\
\hline & & 10 & 5.4 & 7.5 & 394 & 0.07 & 0.38 \\
\hline & \multirow[t]{2}{*}{ June } & 1 & 23.3 & 8.5 & 378 & 0.03 & 0.64 \\
\hline & & 10 & 5.3 & 7.4 & 397 & 0.06 & 1.41 \\
\hline & \multirow[t]{2}{*}{ July } & 1 & 23.4 & 8.6 & 375 & 0.17 & 0.79 \\
\hline & & 10 & 6.4 & 7.6 & 396 & 0.05 & 1.08 \\
\hline & \multirow[t]{2}{*}{ August } & 1 & 22.5 & 8.5 & 369 & 0.10 & 0.62 \\
\hline & & 10 & 6.4 & 7.7 & 398 & 0.26 & 0.67 \\
\hline \multirow[t]{8}{*}{ Rzęśniki } & \multirow[t]{2}{*}{ May } & 1 & 13.2 & 8.3 & 392 & 0.03 & 0.41 \\
\hline & & 10 & 4.7 & 7.5 & 406 & 0.09 & 1.05 \\
\hline & \multirow[t]{2}{*}{ June } & 1 & 23.2 & 8.3 & 384 & 0.01 & 0.78 \\
\hline & & 10 & 4.8 & 7.4 & 406 & 0.05 & 0.82 \\
\hline & \multirow[t]{2}{*}{ July } & 1 & 23.8 & 8.4 & 383 & 0.07 & 0.80 \\
\hline & & 10 & 5.1 & 7.5 & 406 & 0.29 & 1.21 \\
\hline & \multirow[t]{2}{*}{ August } & 1 & 22.8 & 8.4 & 372 & 0.08 & 0.58 \\
\hline & & 10 & 5.3 & 7.6 & 407 & 0.12 & 0.90 \\
\hline \multirow[t]{8}{*}{ Żabińskie } & \multirow[t]{2}{*}{ May } & 1 & 13.0 & 8.8 & 370 & 0.06 & 2.07 \\
\hline & & 10 & 6.0 & 7.6 & 432 & 0.07 & 1.60 \\
\hline & \multirow[t]{2}{*}{ June } & 1 & - & - & - & 0.09 & 1.24 \\
\hline & & 10 & - & - & - & 0.22 & 2.30 \\
\hline & \multirow[t]{2}{*}{ July } & 1 & 23.7 & 8.8 & 325 & 0.06 & 1.14 \\
\hline & & 10 & 6.1 & 7.6 & 436 & 0.18 & 2.39 \\
\hline & \multirow[t]{2}{*}{ August } & 1 & 22.7 & 8.7 & 340 & 0.16 & 0.59 \\
\hline & & 10 & 6.1 & 7.6 & 438 & 0.23 & 2.04 \\
\hline
\end{tabular}

Note: T—water temperature; EC—electric conductivity; TP—total phosphorus; TN—total nitrogen.

\subsection{Determination of the Allelopathic Activity of Synechococcus Exudates}

Determination of the allelopathic activity of Synechococcus sp. exudates on phytoplankton assemblages was tested according to the methods described by Śliwińska-Wilczewska et al. [21]. The experiments were conducted on the freshwater picocyanobacterium Synechococcus sp. (CCBA AR-258, Figure 6). This specific strain of picocyanobacteria was used in this study due to its previously detected allelopathic activity (data not shown). This strain was maintained as unispecies cultures in the Culture Collection of Baltic Algae (University of Gdańsk, Poland). Synechococcus sp. was grown in $\mathrm{f} / 2$ culture medium [76] in $100 \mathrm{~mL}$ glass flasks. Culture media was prepared with distilled water and autoclaved $\left(15 \mathrm{~min}, 121^{\circ} \mathrm{C}\right)$. The picocyanobacterial culture was kept in a culture room at $20^{\circ} \mathrm{C}$ with a $16: 8 \mathrm{~h}$ light:dark cycle at $50 \mu \mathrm{mol}$ photons $\mathrm{m}^{-2} \mathrm{~s}^{-1}$ of photosynthetically active radiation (PAR). The phytoplankton communities used for the experiment was taken from the same lakes and at the same time as the phytoplankton used for the biological analysis: for species composition and biomass calculation, see Subsection 4.2. The samples were filtered through a $150 \mu \mathrm{m}$ mesh-size nylon net to remove the effect of grazing by mesozooplankton. The phytoplankton assemblages used in the experiments were kept under a temperature of $20^{\circ} \mathrm{C}$ and light intensity of $50 \mu \mathrm{mol}$ photons $\mathrm{m}^{-2} \mathrm{~s}^{-1}$ (PAR) for 21 days before the experiments to acclimatize the collected material to these conditions. 


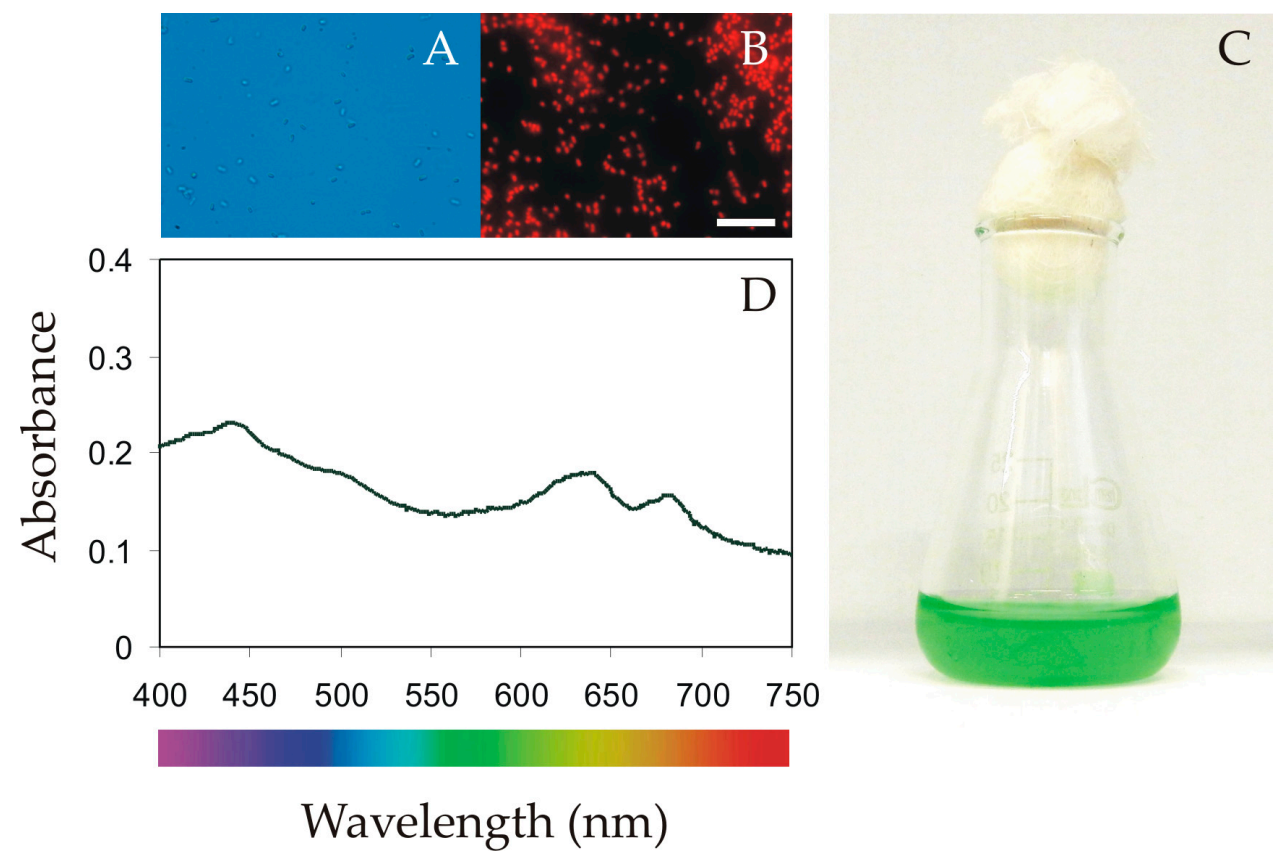

Figure 6. Light (A) and epifluorescence (B) microscope photographs of picocyanobacteria strain CCBA AR-258 (scale $=10 \mu \mathrm{m}$ ); photographs of the picocyanobacterial culture in $100 \mathrm{~mL}$ glass flasks from the experimental phase $(\mathbf{C})$; and PAR absorption spectra determined for this strain at an optical density $\left(\mathrm{OD}_{750}\right)=0.1(\mathbf{D})$.

The allelopathic activity was estimated by adding a specific volume $(10 \mathrm{~mL})$ of the exudates obtained from donor picocyanobacterial culture to the phytoplankton assemblages $(10 \mathrm{~mL}) \mathrm{kept}$ in $25 \mathrm{~mL}$ glass flasks. Controls consisted of the addition of $10 \mathrm{~mL}$ of $\mathrm{f} / 2$ medium to the $25 \mathrm{~mL}$ flasks containing $10 \mathrm{~mL}$ of the phytoplankton assemblages. The nutrient level was tested to make sure that it was the same as in the portions of fresh $\mathrm{f} / 2$ medium added in the control samples according to the methodology proposed by Śliwińska-Wilczewska and Latała [23]. The Synechococcus sp. culture was gently filtered through a $0.45-\mu \mathrm{m}$ membrane filter (Macherey-Nagel, Germany) using a vacuum pump. The cell abundance in the donor Synechococcus sp. cultures was $10^{6} \mathrm{~mL}^{-1}$. This concentration was selected to represent the appropriate environmental conditions, and high enough to be measured properly. The exudates were analyzed on an epifluorescence microscope (Nikon Eclipse 80i, Japan) to confirm the absence of the picocyanobacteria cells. The time of the experimental phase was 1 week, and all treatments were analyzed in independent triplicates.

\subsection{Statistical Analyses}

One-way ANOVA was used to test the effect of picocyanobacterial exudates on the number of cells and biomass of the targeted cyanobacteria and microalgae on the last day of the experiment. Data are reported as means \pm standard deviations (SD). Levels of significance were ${ }^{*} p<0.05 ;{ }^{* *} p<0.01$; ${ }_{* * *}^{*}<0.001$. The statistical analyses were performed using Statistica ${ }^{\circledR} 13.1$ software.

Supplementary Materials: The following are available online at http://www.mdpi.com/2072-6651/12/4/259/s1, Table S1. List of species detected in three lakes ( $\mathrm{L}, \mathrm{RL}$, and ŻL) in the study period. Table S2. List of species detected in ŁL in controls and the experiments after 7 days of exposition to the exudates from Synechococcus sp. in the study period. Table S3. List of species detected in RL in controls and the experiments after 7 days of exposition to the exudates from Synechococcus sp. in the study period. Table S4. List of species detected in ŻL in controls and the experiments after 7 days of exposition to the exudates from Synechococcus sp. in the study period.

Author Contributions: Methodology, I.B., P.G., A.S., K.M. and S.Ś.-W.; writing-original draft, I.B. and S.Ś.-W. All the authors were involved in the preparation of this manuscript. All authors have read and agreed to the published version of the manuscript. 
Funding: This research was funded by National Science Centre, grant number 2015/18/E/ST10/00325.

Acknowledgments: The authors would like to thank the anonymous reviewers for their valuable comments and suggestions to improve the quality of the paper. We would like to sincerely thank Wojciech Tylmann for the opportunity to join to the research team.

Conflicts of Interest: The authors declare no conflict of interest.

\section{References}

1. Rumin, J.; Nicolau, E.; Junior, R.G.D.O.; Fuentes-Grünewald, C.; Flynn, K.J.; Picot, L. A bibliometric analysis of microalgae research in the world, Europe, and the European Atlantic area. Mar. Drugs 2020, 18, 79. [CrossRef] [PubMed]

2. Burchard, L. Key to Identification of Phytoplankton Species in Lakes and Rivers. Guide for Laboratory Classes and Field Research; W. Szafer Institute of Botany, Polish Academy of Sciences: Kraków, Poland, 2014; pp. 1-179.

3. Naselli-Flores, L.; Padisak, J.; Albay, M. Shape and size in phytoplankton ecology: Do they matter? Hydrobiologia 2000, 578, 157-161. [CrossRef]

4. Maberly, S.C.; King, L.; Dent, R.R.; Jones, R.I.; Gibson, C.E. Nutrient limitation of phytoplankton and periphyton growth in upland lakes. Freshw. Biol. 2002, 47, 2136-2152. [CrossRef]

5. SOlitude Lake Management. Phytoplankton: Get to Know Your Pond Algae. 2017. Available online: https: //www.solitudelakemanagement.com/blog/author/solitude-lake-management (accessed on 27 February 2020).

6. Schindler, D.W.; Hecky, R.E.; Findlay, D.L.; Stainton, M.P.; Parker, B.R.; Paterson, M.J.; Beaty, K.G.; Lyng, M.; Kasian, S.E.M. Eutrophication of lakes cannot be controlled by reducing nitrogen input: Results of a 37-year whole-ecosystem experiment. Proc. Natl. Acad. Sci. USA 2008, 105, 11254-11258. [CrossRef]

7. Schindler, D.W. The dilemma of controlling cultural eutrophication of lakes. Proc. R. Soc. 2012, $279,4322-4333$. [CrossRef]

8. Paerl, H.W. Mitigating toxic planktonic cyanobacterial blooms in aquatic ecosystems facing increasing anthropogenic and climatic pressures. Toxins 2018, 10, 76. [CrossRef]

9. They, N.H.; Marques, D.M.; Crossetti, L.O.; Becker, V.; Canterle, E.; Ribeiro Rodrigues, L.; Cardoso, L.; Fragoso, C.R. Júnior. Phytoplankton ecological interactions in freshwater ecosystems-Integrating relationships in subtropical shallow lakes. In Phytoplankton: Biology, Classification and Environmental Impacts, 1st ed.; Sebastiá, M.T., Ed.; NOVA Publishers: New York, NY, USA, 2014; pp. 73-130.

10. Leão, P.N.; Vasconcelos, M.T.S.D.; Vasconcelos, V.M. Allelopathy in freshwater cyanobacteria. Crit. Rev. Microbiol. 2009, 35, 271-282. [CrossRef]

11. Brutemark, A.; Vandelannoote, A.; Engström-Öst, J.; Suikkanen, S. A less saline Baltic Sea promotes cyanobacterial growth, hampers intracellular microcystin production, and leads to strain-specific differences in allelopathy. PLoS ONE 2015, 10, 6. [CrossRef] [PubMed]

12. Żak, A.; Kosakowska, A. The influence of extracellular compounds produced by selected Baltic cyanobacteria, diatoms and dinoflagellates on growth of green algae Chlorella vulgaris. Estuar. Coast. Shelf Sci. 2015, 167, 113-118. [CrossRef]

13. Pichierri, S.; Accoroni, S.; Pezzolesi, L.; Guerrini, F.; Romagnoli, T.; Pistocchi, R.; Totti, C. Allelopathic effects of diatom filtrates on the toxic benthic dinoflagellate Ostreopsis cf. ovata. Mar. Environ. Res. 2017, 131, 116-122. [CrossRef] [PubMed]

14. Van Meerssche, E.; Pinckney, J.L. The influence of salinity in the domoic acid effect on estuarine phytoplankton communities. Harmful Algae 2017, 69, 65-74. [CrossRef]

15. Poulin, R.X.; Hogan, S.; Poulson-Ellestad, K.L.; Brown, E.; Fernández, F.M.; Kubanek, J. Karenia brevis allelopathy compromises the lipidome, membrane integrity, and photosynthesis of competitors. Sci. Rep. 2018, 8, 1-9. [CrossRef]

16. Poulin, R.X.; Poulson-Ellestad, K.L.; Roy, J.S.; Kubanek, J. Variable allelopathy among phytoplankton reflected in red tide metabolome. Harmful Algae 2018, 71, 50-56. [CrossRef]

17. Kovács, A.W.; Tóth, V.R.; Pálffy, K. The effects of interspecific interactions between bloom forming cyanobacteria and Scenedesmus quadricauda (chlorophyta) on their photophysiology. Acta Biol. Hung. 2018, 69, 210-223. [CrossRef] 
18. Śliwińska-Wilczewska, S.; Pniewski, F.; Latała, A. Allelopathic activity of the picocyanobacterium Synechococcus sp. under varied light, temperature and salinity conditions. Int. Rev. Hydrobiol. 2016, 101, 69-77. [CrossRef]

19. Śliwińska-Wilczewska, S.; Pniewski, F.; Latała, A. Allelopathic interactions between Synechococcus sp. and Nodularia spumigena under different light conditions. Allelopathy J. 2016, 37, 241-252.

20. Śliwińska-Wilczewska, S.; Maculewicz, J.; Barreiro Felpeto, A.; Vasconcelos, V.; Latała, A. Allelopathic activity of the picocyanobacterium Synechococcus sp. on filamentous cyanobacteria. J. Exp. Mar. Biol. Ecol. 2017, 496, 16-21. [CrossRef]

21. Śliwińska-Wilczewska, S.; Maculewicz, J.; Tuszer, J.; Dobosz, K.; Kalusa, D.; Latała, A. First record of allelopathic activity of the picocyanobacterium Synechococcus sp. on a natural plankton community. Ecohydrol. Hydrobiol. 2017, 17, 227-234. [CrossRef]

22. Śliwińska-Wilczewska, S.; Barreiro Felpeto, A.; Maculewicz, J.; Sobczyk, A.; Vasconcelos, V.; Latała, A. Allelopathic activity of the picocyanobacterium Synechococcus sp. on unicellular eukaryote planktonic microalgae. Mar. Freshwater Res. 2018, 69, 1472-1479. [CrossRef]

23. Śliwińska-Wilczewska, S.; Latała, A. Allelopathic activity of the bloom-forming picocyanobacterium Synechococcus sp. on the coexisting microalgae: the role of eutrophication. Int. Rev. Hydrobiol. 2018, 103, 37-47. [CrossRef]

24. Śliwińska-Wilczewska, S.; Barreiro Felpeto, A.; Możdżeń, K.; Vasconcelos, V.; Latała, A. Physiological Effects on Coexisting Microalgae of the Allelochemicals Produced by the Bloom-Forming Cyanobacteria Synechococcus sp. and Nodularia spumigena. Toxins 2019, 11, 712. [CrossRef] [PubMed]

25. Barreiro Felpeto, A.; Śliwińska-Wilczewska, S.; Złoch, I.; Vasconcelos, V. Light-dependent cytolysis in the allelopathic interaction between picoplanktic and filamentous cyanobacteria. J. Plankton Res. 2018, 40, 165-177. [CrossRef]

26. Konarzewska, Z.; Śliwińska-Wilczewska, S.; Barreiro Felpeto, A.; Vasconcelos, V.; Latała, A. Assessment of the Allelochemical Activity and Biochemical Profile of Different Phenotypes of Picocyanobacteria from the Genus Synechococcus. Mar. Drugs 2020, 18, 179. [CrossRef]

27. Paz-Yepes, J.; Brahamsha, B.; Palenik, B. Role of a Microcin-C-like biosynthetic gene cluster in allelopathic interactions in marine Synechococcus. Proc. Natl. Acad. Sci. USA 2013, 110, 12030-12035. [CrossRef] [PubMed]

28. Barreiro Felpeto, A.; Śliwińska-Wilczewska, S.; Klin, M.; Konarzewska, Z.; Vasconcelos, V. Temperaturedependent impacts of allelopathy on growth, pigment, and lipid content between a subpolar strain of Synechocystis sp. CCBA MA-01 and coexisting microalgae. Hydrobiologia 2019, 835, 117-128. [CrossRef]

29. Martins, R.F.; Ramos, M.F.; Herfindal, L.; Sousa, J.A.; Skærven, K.; Vasconcelos, V.M. Antimicrobial and cytotoxic assessment of marine cyanobacteria-Synechocystis and Synechococcus. Mar. Drugs 2008, 6, 1-11. [CrossRef]

30. Frazão, B.; Martins, R.; Vasconcelos, V. Are known cyanotoxins involved in the toxicity of picoplanktonic and filamentous north atlantic marine cyanobacteria? Mar. Drugs 2010, 8, 1908-1919. [CrossRef]

31. Costa, M.S.; Costa, M.; Ramos, V.; Leão, P.N.; Barreiro, A.; Vasconcelos, V.; Martins, R. Picocyanobacteria from a clade of marine cyanobium revealed bioactive potential against microalgae, bacteria, and marine invertebrates. Toxicol. Environ. Health Part A 2015, 78, 432-442. [CrossRef]

32. Hamilton, T.J.; Paz-Yepes, J.; Morrison, R.A.; Palenik, B.; Tresguerres, M. Exposure to bloom-like concentrations of two marine Synechococcus cyanobacteria (strains CC9311 and CC9902) differentially alters fish behaviour. Conserv. Physiol. 2014, 2, 1-9. [CrossRef]

33. Worden, A.Z.; Wilken, S. A plankton bloom shifts as the ocean warms. Science 2016, 354, 287-288. [CrossRef]

34. Jasser, I.; Callieri, C. Picocyanobacteria. In Handbook on Cyanobacterial Monitoring and Cyanotoxin Analysis; Meriluoto, J., Spoof, L., Codd, G.A., Eds.; John Wiley \& Sons, Ltd.: Hoboken, NJ, USA, 2017; pp. 19-27.

35. Śliwińska-Wilczewska, S.; Cieszyńska, A.; Maculewicz, J.; Latała, A. Ecophysiological characteristics of red, green, and brown strains of the Baltic picocyanobacterium Synechococcus sp.-A laboratory study. Biogeosciences 2018, 15, 6257-6276. [CrossRef]

36. Stockner, J.; Callieri, C.; Cronberg, G. Picoplankton and other non-bloom forming cyanobacteria in lakes. In The Ecology of Cyanobacteria: Their Diversity in Time and Space; Whitton, B., Potts, M., Eds.; Kluwer Academic Publishers: Dordrecht, UK, 2000; pp. 195-238.

37. Phlips, E.J.; Badylak, S.; Lynch, T.C. Blooms of the picoplanktonic cyanobacterium Synechococcus in Florida Bay, a subtropical inner-shelf lagoon. Limnol. Oceanogr. 1999, 14, 1166-1175. [CrossRef] 
38. Sorokin, P.Y.; Sorokin, Y.I.; Boscolo, R.; Giovanardi, O. Bloom of picocyanobacteria in the Venice lagoon during summer-autumn 2001: Ecological sequences. Hydrobiologia 2004, 523, 71-85. [CrossRef]

39. Sorokin, Y.I.; Zakuskina, O.Y. Features of the Comacchio ecosystem transformed during persistent bloom of picocyanobacteria. J. Oceanogr. 2010, 66, 373-387. [CrossRef]

40. Li, J.; Chen, Z.; Jing, Z.; Zhou, L.; Li, G.; Ke, Z.; Tan, Y. Synechococcus bloom in the Pearl River Estuary and adjacent coastal area-With special focus on flooding during wet seasons. Sci. Total Environ. 2019, 692, 769-783. [CrossRef] [PubMed]

41. Ciscar, J.C.; Feyen, L.; Soria, A. Climate impacts in Europe; The JRC PESETA II Project, JRC Scientific and Politicy Reports, EUR 26586EN; EUR-Scientific and Technical Research, Joint Research Centre of the European Commission: Seville, Spain, 2014; p. 155.

42. Flombaum, P.; Gallegos, J.L.; Gordillo, R.A.; Rincon, J.; Zabala, L.L.; Jiao, N.; Karl, D.M.; Li, W.K.; Lomas, M.W.; Veneziano, D. Present and future global distributions of the marine Cyanobacteria Prochlorococcus and Synechococcus. Proc. Natl. Acad. Sci. USA 2013, 110, 9824-9829. [CrossRef]

43. Dutkiewicz, S.; Morris, J.J.; Follows, M.J.; Scott, J.; Levitan, O.; Dyhrman, S.T.; Berman-Frank, I. Impact of ocean acidification on the structure of future phytoplankton communities. Nat. Clim. Chang. 2015, 5, 1002-1006. [CrossRef]

44. Śliwińska-Wilczewska, S.; Maculewicz, J.; Barreiro Felpeto, A.; Latała, A. Allelopathic and bloom-forming picocyanobacteria in a changing world. Toxins 2018, 10, 48. [CrossRef]

45. Suikkanen, S.; Fistarol, G.O.; Granéli, E. Allelopathic effects of the Baltic cyanobacteria Nodularia spumigena, Aphanizomenon flos-aquae and Anabaena lemmermannii on algal monocultures. J. Exp. Mar. Biol. Ecol. 2004, 308, 85-101. [CrossRef]

46. Gleason, F.K.; Baxa, C.A. Activity of the natural algicide, cyanobacterin, on eukaryotic microorganisms. FEMS Microbiol. Lett. 1986, 33, 85-88. [CrossRef]

47. Gleason, F.K. The natural herbicide, cyanobacterin, specifically disrupts thylakoid membrane structure in Euglena gracilis strains Z. FEMS Microbiol. Lett. 1990, 68, 77-82. [CrossRef]

48. Bagchi, S.N.; Palod, A.; Chauhan, V.S. Algicidal properties of a bloom-forming blue-green-alga, Oscillatoria sp. J. Basic Microbiol. 1990, 30, 21-29. [CrossRef]

49. Bagchi, S.N.; Chauhan, V.S.; Marwaii, J.B. Effect of an antibiotic from Oscillatoria late-virens on growth, photosynthesis, and toxicity of Microcystis aeruginosa. Curr. Microbiol. 1993, 26, 223-228. [CrossRef]

50. Issa, A.A. Antibiotic production by the cyanobacteria Oscillatoria angustissima and Calothrix parietina. Environ. Toxicol. Pharmacol. 1999, 8, 33-37. [CrossRef]

51. Schagerl, M.; Unterrieder, I.; Angeler, D.G. Allelopathy among cyanoprokaryota and other algae originating from Lake Neusiedlersee (Austria). Int. Rev. Hydrobiol. 2002, 87, 365-374. [CrossRef]

52. Valdor, R.; Aboal, M. Effects of living cyanobacteria, cyanobacterial extracts and pure microcystins on growth and ultrastructure of microalgae and bacteria. Toxicon 2007, 49, 769-779. [CrossRef]

53. Rzymski, P.; Poniedziałek, B.; Kokociński, M.; Jurczak, T.; Lipski, D.; Wiktorowicz, K. Interspecific allelopathy in cyanobacteria: Cylindrospermopsin and Cylindrospermopsis raciborskii effect on the growth and metabolism of Microcystis aeruginosa. Harmful Algae 2014, 35, 1-8. [CrossRef]

54. Swift, S.; Bainton, N.J.; Winson, M.K. Gram-negative bacterial communication by N-acyl homoserine lactones: a universal language? Trends Microbiol. 1994, 2, 193-198. [CrossRef]

55. Pushparaj, B.; Pelosi, E.; Jüttner, F. Toxicological analysis of the marine cyanobacterium Nodularia harveyana. J. Appl. Phycol. 1999, 10, 527-530. [CrossRef]

56. Gross, E.M. Allelopathy of aquatic autotrophs. Crit. Rev. Plant Sci. 2003, 22, 313-339. [CrossRef]

57. Suikkanen, S.; Fistarol, G.O.; Granéli, E. Effects of cyanobacterial allelochemicals on a natural plankton community. Mar. Ecol. Prog. Ser. 2005, 287, 1-9. [CrossRef]

58. Żak, A.; Musiewicz, K.; Kosakowska, A. Allelopathic activity of the Baltic cyanobacteria against microalgae. Estuar. Coast. Shelf Sci. 2012, 112, 4-10. [CrossRef]

59. Wang, L.; Zi, J.; Xu, R.; Hilt, S.; Hou, X.; Chang, X. Allelopathic effects of Microcystis aeruginosa on green algae and a diatom: Evidence from exudates addition and co-culturing. Harmful Algae 2017, 61, 56-62. [CrossRef]

60. Ma, Z.L.; Fang, T.X.; Thring, R.W.; Li, Y.B.; Yu, H.G.; Zhou, Q.; Zhao, M. Toxic and non-toxic strains of Microcystis aeruginosa induce temperature dependent allelopathy toward growth and photosynthesis of Chlorella vulgaris. Harmful Algae 2015, 48, 21-29. [CrossRef] 
61. Schlegel, I.; Doan, N.T.; de Chazal, N.; Smith, G.D. Antibiotic activity of new cyanobacterial isolates from Australia and Asia against green algae and cyanobacteria. J. Appl. Phycol. 1999, 10, 471-479. [CrossRef]

62. Song, H.; Lavoie, M.; Fan, X.; Tan, H.; Liu, G.; Xu, P.; Fu, Z.; Paerl, H.W.; Qian, H. Allelopathic interactions of linoleic acid and nitric oxide increase the competitive ability of Microcystis aeruginosa. ISME J. 2017, 11, 1865-1876. [CrossRef]

63. Lam, C.W.Y.; Silvester, W.B. Growth interactions among blue-green (Anabaena oscillarioides, Microcystis aeruginosa) and green (Chlorella sp.) algae. Hydrobiologia 1979, 63, 135-143. [CrossRef]

64. Gantar, M.; Berry, J.P.; Thomas, S.; Wang, M.; Perez, R.; Rein, K.S. Allelopathic activity among cyanobacteria and microalgae isolated from Florida freshwater habitats. FEMS Microbiol. Ecol. 2008, 64, 55-64. [CrossRef]

65. Keating, K.I. Allelopathic Influence on Blue-Green Bloom Sequence in a Eutrophic Lake. Science 1977, 196, 885-887. [CrossRef]

66. Keating, K.I. Blue-green algal inhibition of diatom growth: Transition from mesotrophic to eutrophic community structure. Science 1978, 199, 971-973. [CrossRef]

67. Lafforgue, M.; Szeligiewicz, W.; Devaux, J.; Poulin, M. Selective mechanisms controlling algal succession in Aydat Lake. Water Sci. Technol. 1995, 32, 117-127. [CrossRef]

68. Choiński, A. Limnologia Fizyczna Polski; Wydawnictwo Naukowe UAM: Poznań, Poland, 2007; p. 548. (In Polish)

69. Szumański, A. Objaśnienia do Szczegótowej Mapy Geologicznej Polski, Arkusz Giżycko (104); Państwowy Instytut Geologiczny: Warszawa, Poland, 2000; p. 33. (In Polish)

70. Carlson, R.E. A Trophic State Index for Lakes. Limnol. Oceanogr. 1977, 22, 361-369. [CrossRef]

71. Jańczak, J. Atlas jezior Polski. Tom 3, Jeziora Pojezierza Mazurskiego i Polski potudniowej (The Atlas of Polish Lakes. Volume 3, Masurian Lakes and the Southern Part of Poland); Bogucki Wydaw: Nauk, Poznań, 1999; p. 240, (In Polish, English summary).

72. SOP for Phytoplankton Analysis-Standard Operating Procedure for Phytoplankton Analysis; Grace Analytical Lab: Chicago, IL, USA, 1994; pp. 367-396.

73. Wołowski, K. Taxonomic and Environmental Studies on Euglenophytes of the Kraków-Częstochowa Upland (Southern Poland); W. Szafer Institute of Botany, Polish Academy of Sciences: Kraków, Poland, 1998; pp. 1-192.

74. Guiry, M.D.; Guiry, G.M. AlgaeBase World-Wide Electronic Publication; National University of Ireland: Galway, Ireland, 2019; Available online: http://www.algaebase.org (accessed on 24 June 2019).

75. Brierley, B.; Carvalho, L.; Davies, S.; Krokowski, J. Guidance on the quantitative analysis of phytoplankton in Freshwater Samples. Report to SNIFFER (Project WFD80), Edinburgh, UK, Phytoplankton Counting Guidance_v1_2007 12 05.doc. 2007, p. 1. Available online: http://nora.nerc.ac.uk/id/eprint/5654/1/Phytoplankton_ Counting_Guidance_v1_2007_12_05.pdf (accessed on 27 February 2020).

76. Guillard, R.R.L. Culture of phytoplankton for feeding marine invertebrates. In Culture of Marine Invertebrate Animals; Smith, W.L., Chanley, M.H., Eds.; Plenum Press: New York, NY, USA, 1975. 